\title{
Voluntary intake of dry matter and performance of Nellore cows and their Nellore and crossbred Simental $\times$ Nellore calves ${ }^{1}$
}

\section{Fernando Miranda de Vargas Junior ${ }^{2}$, Francisco Stefano Wechsler ${ }^{3}$, Patrícia Rossi ${ }^{4}$, Marcus Vinicius Morais de Oliveira $^{5}$, Patrick Schmidt ${ }^{6}$}

\footnotetext{
1 Pesquisa financiada pela FAPESP/CAPES.

2 Universidade Federal da Grande Dourados/Faculdade de Ciências Agrárias, Rodovia Dourados - Itahum, km 12, Caixa Postal 533, 79804-970 - Dourados, MS.

3 Universidade Estadual Paulista/Faculdade de Medicina Veterinária e Zootecnia - Departamento de Exploração e Produção Animal, Botucatu, SP.

4 University of Kentucky/Department Animal and Food Sciences/Lexington, $K Y$.

5 Universidade Estadual de Mato Grosso do Sul/Curso de Zootecnia, Aquidauana, MS.

6 Universidade Federal do Paraná/Departamento de Zootecnia, Curitiba, PR.
}

\begin{abstract}
This study aimed to investigate the influence of calf genetic group on the performance of Nellore lactating cows. The variables studied included milk ingestion, pasture intake, calf weight gain and cow body weight. A total of 13 Nellore calves and 8 crossbred Simental $\times$ Nellore calves were used, all born from Nellore mothers. During the experimental period of 210 days, calves were weighted at birth and at 30-day intervals, whereas cows were weighed every 14 days. Milk intake was estimated using the weigh-suckle-weigh method. Pasture intake was determined 6, 12, and 24 weeks after birth by using chromic oxide as an external marker and indigestible acid detergent fiber as an internal marker. Average weight of crossbred calves was $10.1 \mathrm{~kg}$ and their milk intake was $0.42 \mathrm{~kg}$ higher than in purebred calves. There was no difference, however, in pasture intake between genetic groups. In Nellore cows, body weight and pasture consumption $(9.2 \mathrm{~kg}$ of DM/cow/day) were not influenced by calf heterosis.
\end{abstract}

Key Words: crossing, grazing, milk, weight gain

\section{Introduction}

Grazing animals can alter the composition of their diet through the selection of consumed material. Therefore, it is of fundamental relevance to determine the consumption and digestibility of different fractions of pasture. However, given that there are several variables that regulate animal appetite, estimating intake, especially of lactating calves, is a challenging task.

Pasture intake is influenced by several variables, such as the amount of available forage, dry matter (DM) digestibility, body weight, age, genetic potential of the animal and environmental conditions, with all of these factors interacting continuously (Rovira, 1996). Thus, weight at weaning is influenced by many factors, yet authors such as Rutledge et al. (1971) have demonstrated that, at this stage, milk ingestion is the most important component of calf growth. Similarly, Fiss \& Wilton (1993) indicated that the best zootechnical indices are associated with higher milk consumption and, therefore, higher calf weight gain. According to Day et al. (1987), between 30 and $40 \%$ of the total growth of an animal occurs until weaning, which usually takes place between the seventh and the eighth months of age. As a consequence, total weight of the calves is a consequence of their mothers' reproductive efficiency and milk production, and that production, in turn, depends on nutrition, age, genetic potential of the cow and genotype of the calf.

The benefits of heterosis on beef cattle production systems is widely known, yet, in general the effect of crossing on the overall efficiency of the raising system has been poorly studied, particularly with respect to Nellore cows. During assessments, usually control groups are not included, which would be composed of purebred zebu calves reared under the same conditions, thus preventing comparisons between mothers of purebred and crossbred calves.

Thus, the objective of the present study is to investigate the influence of heterosis on the performance of lactating calves and the effects on purebred Nellore mother cows. The hypothesis being tested is whether higher demands from the calf could elevate milk production and forage consumption by the mother. In addition, another goal of this study is to verify if crossbred calves would start feeding on forage earlier or at amounts higher than purebred calves. As a consequence, the higher intake by the cow 
and/or calf would indicate the need for lower forage pressure in cows producing crossbred calves.

\section{Material and Methods}

This study was carried out in the Fazenda Experimental São Manuel, which belongs to the Universidade Estadual Paulista (UNESP) - Faculdade de Medicina Veterinária e Zootecnia, located in the municipality of São Manuel, state of São Paulo.

From a stock of 52 Nellore cows, half were randomly chosen for artificial insemination with semen from a Nellore bull and the other half with semen from a Simental bull. Both bulls had expected difference in progeny for gain in weight close to zero. A total of 37 primiparous and pluriparous gave birth to 24 Nellore calves and 13 1/2 Simental $\times 1 / 2$ Nellore calves. A group of 21 cows were selected and distributed according to the genetic group of the calves, i.e. a Nellore group composed of 13 cows with purebred calves, four males and nine females, and a Simental group composed of 8 cows with crossbred calves, four males and nine females.

Based on the date of birth (December $1^{\text {st }}$ to January $31^{\text {st }}$ ), cows were randomly assigned into three groups, with an interval of 20 days between groups, as follows: group A: five cows, with 2 Nellore calves and 3 crossbred calves; group B: nine cows, with 7 Nellore calves and 2 crossbred calves; and group C: seven cows, with 4 Nellore calves and 3 crossbred calves.

Calves were weighted up to weaning, at 30-day intervals, according to their respective group. All cows were weighted until weaning, but at a 14-day interval. All animals were kept in a pasture of Brachiaria decumbens, with a few Brachiaria brizantha patches, and subdivided into 14 paddocks, with an average density of $0.7 \mathrm{AU} / \mathrm{ha}$. Soon after birth, calves and mothers were taken to a barn and weighed. Later, each calf was subjected to navel treatment, received a tattoo and an earring for identification and received a dose of ivermectin. Subsequently, animals were dewormed and vaccinated against foot-and-mouth and clostridial diseases.

Milk production was always determined before the beginning of the estimate pasture consumption on the $3^{\text {rd }}$, $6^{\text {th }}, 12^{\text {th }}$ and $24^{\text {th }}$ weeks. The method used to measure milk production was indirect, i.e., the difference between the weight of the calf before and after feeding, according to procedure described below. At 10 p.m. of the day prior to measurement, calves were separated from the cows and put to suckle at 5:30 p.m. of the same day, for 30 minutes, in order to empty the udders, and again, at 6 p.m., they were separated from mothers. Calves fasted for 12 hours total, and at 6 p.m. on the following day, having been previously weighed, they were placed with the cows to feed; when all finished sucking, they were separated and weighed again. The estimate of milk yield obtained by the difference of weights before and after feeding was corrected to 24 hours, and these data were used to estimate the total yield between 21 days and 168 days of lactation by integrating the lactation curve in this interval.

The voluntary dry matter intake from pasture was estimated at 6,12 and 24 weeks postpartum. Chromic oxide was used as an external marker to estimate fecal output, given orally once a day (Langlands et al. 1963; Owens \& Hanson, 1992) at 10 a.m., during 11 days in a serving of $15 \mathrm{~g}$ for the cows and 2, 2.5 or $4 \mathrm{~g}$ for calves in the three measurement periods, respectively. These portions were packaged in a paper cartridge and directly introduced into the esophagus through the rubber tube. The first seven days were used for the indicator to reach equilibrium within the gastrointestinal tract and, during the next five days, stool was collected at the time of each dosage. Approximately $150 \mathrm{~g}$ of feces were collected directly from the rectum of the animals, and these samples were placed in plastic bags and frozen, and subsequently dried in a forced circulation oven at $60^{\circ} \mathrm{C}$ for about 72 hours. After drying, samples were ground and mixed to form a composite sample per animal in each assessment period.

Sampling of pasture intake was obtained using two esophageal fistulated animals. During the five days of stool collection, animals were arranged so that one of the fistulated animals was placed together with a group of cows and calves whose consumption was being measured. The fistulated animal was removed at the time of taking the animals to the barn for sampling feces. Food samples collected from each fistulated animal were frozen and subsequently dried, ground and submitted to bromatological analysis.

The supply of dry matter available in the paddock was always estimated in the same week when consumption was measured. For this, a $25 \mathrm{~cm}$-sided square was thrown randomly during a walk around the paddock (Hodgson et al., 2000). The forage contained in the square was cut approximately $5 \mathrm{~cm}$ off the soil. The process was repeated ten times to form a composite sample, which was taken to the laboratory, still heavy green, dried in forced ventilation oven at $60{ }^{\circ} \mathrm{C}$ for 72 hours, ground and stored.

Samples of the food consumed and feces were analyzed for composition in dry matter (DM) and crude protein (CP), according to AOAC (1995); neutral detergent fiber (NDF) and acid detergent fiber (ADF), according to Goering \& Van Soest (1970), and indigestible ADF (iADF), which served as an internal marker, through 144 hours of incubation in the 
rumen of two steers fitted with rumen cannula, according to Penning \& Johnson (1983). The concentrations of chromium were also determined in feces according to methodology of digestion and solubilization described by Bremer Neto (2005), and reading done by atomic absorption spectrometry and atomic flame absorption.

To estimate the digestibility (D) of DM in cows, the following formula was employed: $\mathrm{D}=1-\mathrm{C}_{\text {Pasture }} / \mathrm{C}_{\mathrm{iADF}}$, where: $\mathrm{C}_{\text {Pasture }}=$ concentration $(\mathrm{g} / \mathrm{g}) \mathrm{iADF}$ grazing consumed $\mathrm{DM}$, and $\mathrm{C}_{\mathrm{iADF}}=$ concentration $(\mathrm{g} / \mathrm{g})$ of $\mathrm{iADF}$ in Fecal DM.

C intake (g DM/Animal/day) was estimated using the following formulas: $\mathrm{C}=\mathrm{F} /(1-\mathrm{d})$ and $\mathrm{F}=$ ( $\mathrm{g}$ Cr supplied/ animal/day) / (g Cr/g Fecal DM), where: F = daily output of fecal DM (g/animal/day).

To estimate dry matter intake of pasture for calves, it was assumed that breast milk contained on average 13.5\% total solids (Felten et al. 1989; Cruz et al., 1997), which allowed for estimating dry matter intake of milk. It was also assumed that the milk contained 92\% digestibility (Baker et al., 1976) and zero content of iADF. Thus, the total fecal output was estimated like in cows. Next, the production of fecal matter attributable to milk was calculated, which was then subtracted from $\mathrm{F}$ for obtention of fecal output attributable to pasture. As the concentration of fecal iADF $\left(\mathrm{C}_{\mathrm{iADF}}\right)$ was the weighted average concentration in feces derived from milk ( $\mathrm{C}_{\mathrm{Fmilk}}$ ) and feces coming from the pasture $\left(\mathrm{C}_{\mathrm{FPasture}}\right)$, it was assumed that $\mathrm{C}_{\text {Fmilk }}$ was zero, thus: $\mathrm{C}_{\text {Fpasture }}=\mathrm{C}_{\mathrm{Feces}} * \mathrm{~F} / \mathrm{F}_{\text {Pasture }}$.

On the other hand, the DM digestibility of the pasture consumed by calves was estimated by the equation: $\mathrm{D}_{\text {Pasture }}=$ $1-C_{\text {Pasture }} / C_{\text {FPasture }}$. Finally, MS was estimated in a similar manner to that used in cows, i. e. $\mathrm{C}=\mathrm{F} /\left(1-\mathrm{D}_{\text {Pasture }}\right)$.

This assay used a randomized blocks design, with more than one repetition per block and repeated measures over time. Results were analyzed statistically by restricted maximum likelihood, using the MIXED procedure (Littell et al., 1996) of SAS (version 6.12). The model included as fixed, genetic group and sex of the calf as the main factors, and the random effect of block, linear effects of body weight and supply of dry matter in pastures as the repeated measures. Also in the repeated measures, the linear and quadratic effects of days postpartum were tested, and their interactions with genetic group and, as covariates, the order of birth (linear and quadratic effect) and milk yield (linear and quadratic effect), assuming a first order autoregressive effect. Random factors included the effects of cows or calves within sex and genotype (error) and residuals (error b).

Total milk production between 21 and 168 days was estimated by integrating the fitted curve in this interval.

To analyze the composition of the material offered and extrusa, a regression model that included the linear effect of week of harvest as main plots and the effects of material (offered or extruded) and interaction between material and weeks as subplots was used. Error (a) was composed of the deviations from the regression, which were assumed to be null. This analysis was performed using the GLM procedure of SAS (version 6.12)

\section{Results and Discussion}

In this assay, there were no significant differences in birth weight between races or genders (Table 1). However, weight gain to weaning was higher in male crossbred Simmental, followed by Nellore males, crossbred females and purebred females (Figure 1), which was expected, primarily due to the effect of heterosis, and, therefore, their gender.

The crossbred calves weighed $10.1 \mathrm{~kg}(6.3 \%)$ more than the purebred at 210 days (Table 1 ). This difference, however, was lower than that reported by Alencar \& Barbosa (1995), who estimated an average of $12 \%$ gain in weaning weight of calves born from crossing Bos taurus bulls with Zebu cows. In this study, probably the quality and availability of pasture at the time of weaning (July-August) have limited the phenotypic expression of the expected advantage in the crossing, but even so, the adjusted weight at 210 days of both genetic groups can be considered good.

Table 1 - Weight of calves, by sex and genetic group, with their regression equations of weight on age

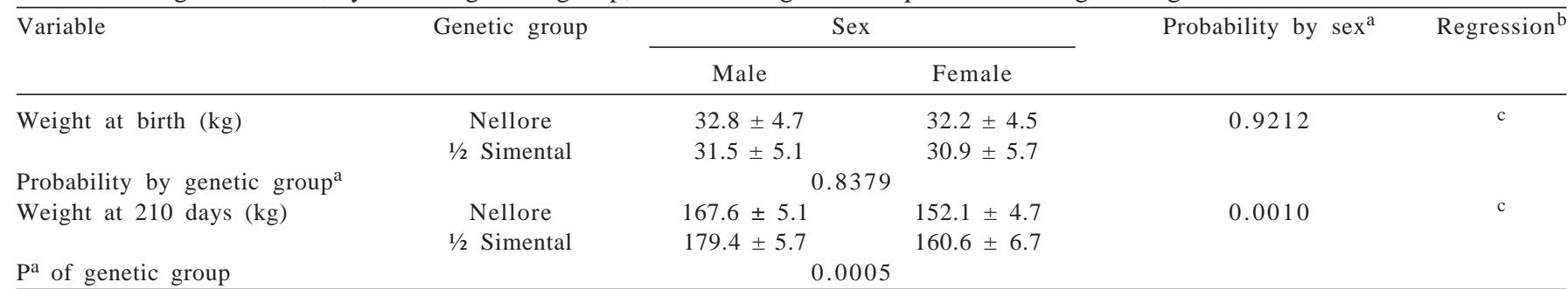

a Probability of type-I error in the difference between means for sex and genetic group.

b Age (I). in days.

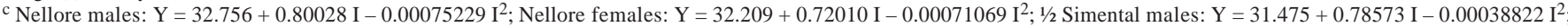
$1 / 2$ Simental females: $\mathrm{Y}=30.928+0.72574 \mathrm{I}-0.00051547 \mathrm{I}^{2}$. 


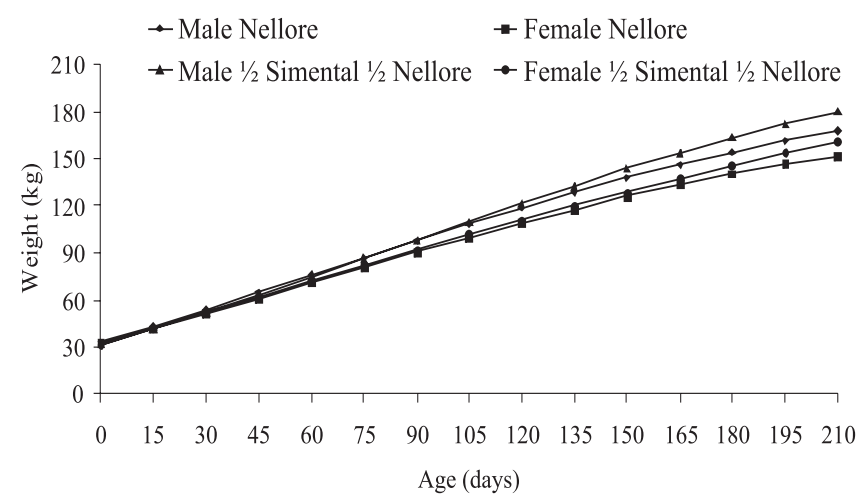

Figure 1 - Adjusted body weight (kg), from birth to weaning, of Nellore and crossbred Simmental $\times$ Nellore calves according to age and sex.

The weight of the cows in the postpartum period did not indicate influence of the genetic group $(\mathrm{P}=0.3913)$ or gender $(\mathrm{P}=0.4958)$ of the calves. Cows lost weight from birth to weaning $(\mathrm{P}=0.0010)$ and mean body weight during the period was $417 \mathrm{~kg}$. A reduction in production/consumption of milk was also verified with the progression of lactation, in quadratic form (Table 2, Figure 2). Alencar et al. (1988) also found a decrease in milk production with advancing lactation, although in linear form.

In this study, despite the effect of the genetic group (Table 3), no effect of calf gender on milk consumption was observed ( $\mathrm{P}=0.6515)$. However, Alencar et al. (1988) and Cruz et al. (1997) reported higher consumption of milk in males. The effect of age was also detected $(\mathrm{P}=0.0636)$ as well as interaction between age and genetic group $(\mathrm{P}=0.0436)$ in milk consumption from 21 to 168 days. In this case, the crossbred calves ingested, on average, over the study period, $0.42 \mathrm{~kg} / \mathrm{animal} / \mathrm{day}$ more milk (Table 3 ). This difference was more prominent before 63 days of age (Figure 2). Moreover, Espasandin et al. (2001) noted no effect of the breed of calf on milk production and also observed that cows that had lower quality food made use of their body reserves while maintaining milk production. Yet Calegari et al. (2009) found an effect of genetic group on milk production, with greater

Table 2 - Means and standard errors of milk consumption of calves (kg/calf/day), according to genetic group, with respective regression equations for consumption by age

\begin{tabular}{lcccc}
\hline Genetic group & Mean & $\begin{array}{c}\text { Standard } \\
\text { error }\end{array}$ & $\mathrm{P}^{\mathrm{a}}$ & Regression $^{\mathrm{b}}$ \\
\hline Nellore & 4.42 & 0.300 & 0.0436 & $\mathrm{c}$ \\
$1 / 2$ Simental $\times 1 / 2$ Nellore & 4.84 & 0.357 & & $\mathrm{~d}$ \\
\hline
\end{tabular}

a Probability of type I error in the difference between means.

b Age (I), in days.

c $\mathrm{Y}=5.35+0.0013 \mathrm{I}-0.000110 \mathrm{I}^{2}$.

${ }^{\mathrm{d}} \mathrm{Y}=7.48-0.0498 \mathrm{I}+0.000141 \mathrm{I}^{2}$.

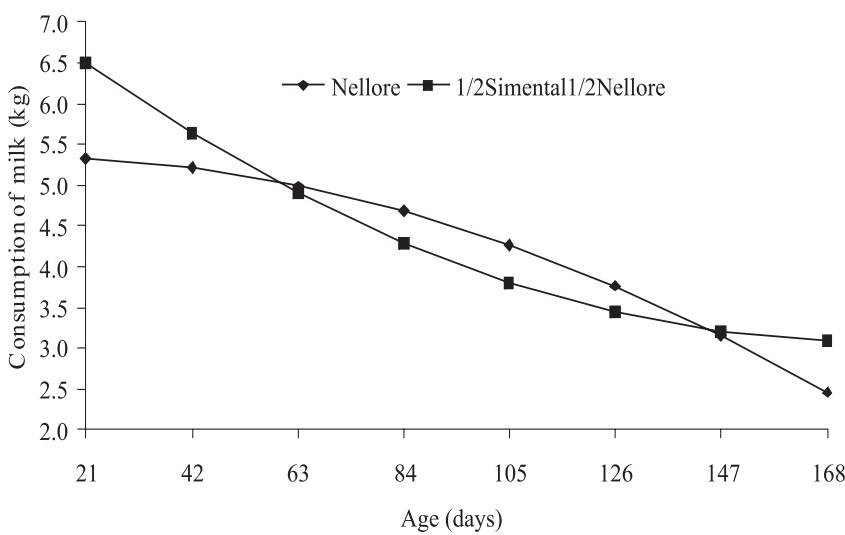

Figure 2 - Consumption of milk of Nellore or crossbred $1 / 2$ Simental $\times 1 / 2$ Nellore calves from 3 to 24 weeks of age.

production for the cows that nursed Nellore crossbred calves (Simmental or Angus A.) than those who breastfed Nellore calves and, at the same time, pairs of cow/calf purebred Nellore required less energy for maintenance, but due to better performance of crossbred calves, all mixbred cow/calf pairs were more efficient.

Vargas Junior et al. (2010) observed, using this same batch of animals, an increase in the frequency of feedings by Nellore calves, but the same overall time spent breastfeeding, which indicates more intensive feeding by crossbred calves.

The total production of milk estimated in the period from 21 to 168 days was $690 \mathrm{~kg} / \mathrm{cow}$ for the mothers of Nellore calves and $707 \mathrm{~kg} / \mathrm{cow}$ for the mothers of $1 / 2$ Simental crossbred calves. Based on these productions and the estimated weight gain of calves from 21 to 168 days, the following feeding conversions were obtained: $6.40,7.19,6.04$ and $6.86 \mathrm{~kg}$ to $1.00 \mathrm{~kg}$ of body weight gain in Nellore males, Nellore females, $1 / 2$ Simmental $1 / 2$ Simmental males and females, respectively, with average conversion of 6.6:1. This conversion was worse than that estimated by Alencar et al. (1996) to purebred Nellore calves, which can be explained by higher consumption of milk observed by these authors. Rovira (1973) remarks that variations in the conversion can occur because the relationship between additional milk consumption and increase in weaning weight depend on the quality of the pasture where the calves are. Therefore, the worse the quality, the more the calves are dependent on consumed milk, and the worse the conversion of milk in weight.

According to Ansotegui et al. (1991), there may be confusion when trying to explain the increased weight gain in the calf by the cow's milk production, since calves tend to consume similar amounts of metabolizable energy per unit weight, i.e., the consumption of milk is smaller, the calf 
Table 3 - Means of pasture dry matter and total (pasture + milk) intake, unadjusted and adjusted for body weight of calves

\begin{tabular}{|c|c|c|c|c|c|}
\hline Consumption (kg/calf/day) & Genetic group or sex of calf & Mean & Standard error & $\mathrm{P}^{\mathrm{a}}$ & Regression $^{\mathrm{b}}$ \\
\hline & \multicolumn{5}{|c|}{ Pasture } \\
\hline \multirow[t]{2}{*}{ Unadjusted for BW } & Nellore & 1.20 & 0.07 & 0.7960 & c \\
\hline & $1 / 2$ Simental & 1.16 & 0.09 & & \\
\hline \multirow[t]{5}{*}{ Adjusted for BW } & Nellore & 1.21 & 0.07 & 0.4174 & d \\
\hline & $1 / 2$ Simental & 1.11 & 0.09 & & \\
\hline & Male & 1.07 & 0.08 & 0.1547 & \\
\hline & Female & 1.25 & 0.08 & & \\
\hline & \multicolumn{5}{|c|}{ Pasture + Milk } \\
\hline \multirow[t]{2}{*}{ Unadjusted for BW } & Nellore & 1.89 & 0.10 & 0.9539 & e \\
\hline & $1 / 2$ Simental & 1.88 & 0.12 & & \\
\hline \multirow[t]{4}{*}{ Adjusted for BW } & Nellore & 1.93 & 0.08 & 0.1615 & f \\
\hline & $1 / 2$ Simental & 1.78 & 0.10 & & \\
\hline & Male & 1.70 & 0.09 & 0.0444 & \\
\hline & Female & 2.00 & 0.09 & & \\
\hline
\end{tabular}

a Probability of type I error in the difference between means.

b Age (I), in days.

c $\mathrm{Y}=-0.72+0.026391 \mathrm{I}-0.000072 \mathrm{I}^{2}$

${ }^{d} \mathrm{Y}=-0.07+0.019108 \mathrm{I}-0.000066 \mathrm{I}^{2}$

e $\mathrm{Y}=-0.24+0.031116 \mathrm{I}-0.000093 \mathrm{I}^{2}$.

${ }^{\mathrm{f}}$ Nellore males: Y $=0.45+0.024186 \mathrm{I}-0.000103 \mathrm{I}^{2}$; Nellore females: Y $=0.75+0.024186 \mathrm{I}-0.000103 \mathrm{I}^{2} ;{ }^{1 / 2} \mathrm{Simental}^{\mathrm{males}}$ Y $=1.52+0.004332 \mathrm{I}-0.000038 \mathrm{I}^{2}$;

$1 / 2$ Simental females: $\mathrm{Y}=1.82+0.004332 \mathrm{I}-0.000038 \mathrm{I}^{2}$.

increases forage intake in an attempt to keep power consumption (Baker et al., 1976; Le Du \& Baker, 1979; Boggs et al., 1980; Grings et al., 1996).

A point to consider is that perhaps the maximum production of a beef cow is determined not only by their physiological capacity to produce milk, but also by the ability of the calf to extract of produced milk. This can be observed in this study, because 1/2 Simmental crossbred calves with higher growth rate and thus increased demand, consumed more milk. Restle et al. (1989) and Moletta et al. (1989), studying the relationship of milk production of two native breeds (Charolais and Nellore) with the purebred performance of their progeny, found no differences between genetic groups in milk production, but observed that the offspring of Charolais cows responds best to increase production of milk then those of Nellore cows. On the other hand, Ribeiro \& Restle (1991), working with two maternal breeds (Charolais and Aberdeen Angus) and four progeny derived from crosses with Nellore calves, had purebred Charolais, Aberdeen Angus and crossbred $1 / 2$ Nellore $\times 1 / 2$ Charolais and $1 / 2$ Nellore $\times 1 / 2$ Aberdeen Angus and found that the average milk production of mothers of crossbred calves was $20.1 \%$ higher than the mothers of purebred calves. Moreover, Ribeiro et al. (1991) observed, in the same genetic groups, production 29\% higher in mothers of crossbred calves. Similarly, in this study, Nellore cows that are mothers to crossbred calves produced $8.7 \%$ more milk, and this smaller difference can be attributed in part to the milk potential of the Nellore, which is smaller than the breeds Charolais and Aberdeen Angus.
Like the quality of pasture, CP content of the extrusa (ingested by fistulated animals) was greater than the available pasture (provided material); on the other hand, NDF, ADF, hemicellulose, cellulose and lignin were lower in the extrusa, indicating the selection made by fistulated animals (Table 4). These results were similar to those observed by Cunha et al. (1992), Berchielli et al. (2002) and Salman et al. (2000).

According to Van Soest (1994), PB concentrations above $7 \%$ did not correlate well with the consumption of grazing animals, but below this level there is a decrease in intake, given that the fiber content of forage has a negative correlation with voluntary intake and becomes limiting when the NDF is above $50 \%$. In this study, the PB of the extrusa fluctuated around $7 \%$, and the NDF was always above $70 \%$. Thus, one can conclude that that PB was not the main limiting consumption, but rather the NDF. Moreover, the $\mathrm{PB}$ and cell wall components in extrusa did not change $(\mathrm{P}>0.10)$ throughout the experiment, while $\mathrm{ADF}(\mathrm{P}=0.0135)$, cellulose $(P=0.0197)$ and lignin $(P=0.0829)$ of the material

Table 4 - Levels of crude protein, neutral detergent fiber, acid detergent fiber, hemicellulose, cellulose and lignin in the pasture (provided material) and extrusive (material ingested by the fistulated animal)

\begin{tabular}{lccc}
\hline Variable & Pasture & Extrusa & Probability $^{\mathrm{b}}$ \\
\hline Crude protein (\%) & 5.23 & 7.79 & 0.0001 \\
Neutral detergent fiber (\%) & 76.8 & 71.39 & 0.0032 \\
Neutral detergent fiber (\%) & 41.97 & 39.76 & 0.0047 \\
Hemicellulose (\%) & 34.83 & 31.63 & 0.0149 \\
Celullose (\%)a & 30.64 & 28.73 & 0.0423 \\
Lignin (\%) & 7.14 & 5.53 & 0.0049 \\
a Variables whose content in the material offered has changed during the evaluation \\
period.
\end{tabular}


offered increased linearly, which demonstrates the ability for section by the animals, despite a reduction in pasture quality. However, in this experiment, the consumption of pasture did not differ between the genetic groups, but there was an increase over time.

The unadjusted consumption of pasture increased linearly $(P=0.0001)$ and quadratically $(P=0.0035)$ in the studied range (Figure 3 ). The consumption of pasture adjusted to body weight also increased linearly $(\mathrm{P}=0.0027)$ and quadratically $(\mathrm{P}=0.0036)$, but tended to stabilize around the $18^{\text {th }}$ week (Figure 4).

These results indicate that the proportion of pasture consumed in relation to body weight increased more rapidly initially, reflecting the growing importance of grazing in the calves. The consumption of milk + pasture unadjusted for body weight increased $(\mathrm{P}=0.0002)$ quadratically $(\mathrm{P}=0.0034)$ and remained similar behavior to unadjusted consumption of pasture, generating curves (pasture and total consumption) almost parallel throughout the period (Figure 3). Given the information provided by Ansotegui et al. (1991), one would expect that, with increasing age and decreasing consumption of milk, the curve of DM intake of pasture would approach the curve of total DM (pasture + milk) regarding the calf's capacity of gradually adjusting its intake, by replacing milk with forage as it grows.

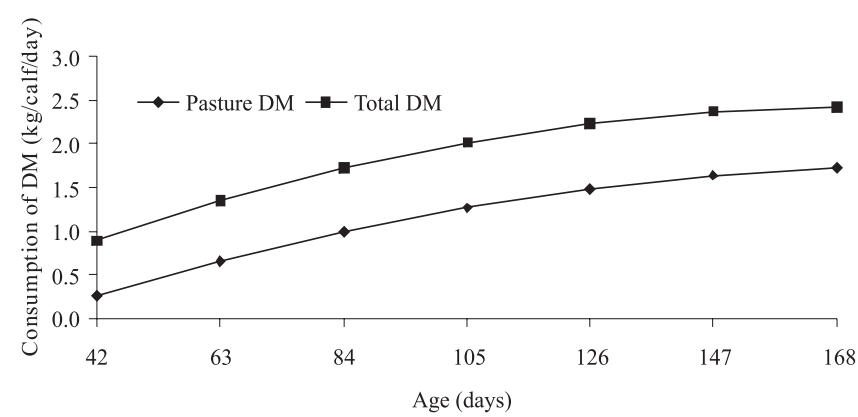

Figure 3 - Consumption of pasture (Pasture DM) of pasture and milk + non-adjusted body weight (total DM) according to the age of the calves.
In the present study, the average BW-adjusted pasture consumption by calves indicated no influence of breed or gender (Table 5); however, there was a quadratic effect $(\mathrm{P}=0.0036)$ of age. In the BW-adjusted consumption of pasture + milk by the calves, a higher mean was observed in females (Table 5), and quadratic effect $(P=0.0067)$ and age interaction ( $\mathrm{P}=0.0285)$, between genetic goup and age. The consumption of milk adjusted to pasture $+\mathrm{PV}$ of crossbred calves showed a peak at 42 days and decreased with age (Figure 4), which was an expected result, given that, with increasing age, the DM of milk becomes an increasingly smaller fraction of total DM as the calf pasture consumption increases in relation to body weight.

The curve of pasture consumption adjusted for body weight approached the curves of consumption of pasture + milk with increasing age of crossbred calves (Figure 4). In this case, the consumption of pasture + milk adjusted to body weight of Nellore calves is difficult to explain, given that it should follow the same trend described by the fitted curves for crossbred calves. Similarly, the highest average intake of pasture + milk adjusted to body weight of females is also outside the expectation because, within each genetic group, females had lower performance compared with males (Table 1; Figure 1), thus not explaining the higher consumtion of DM.

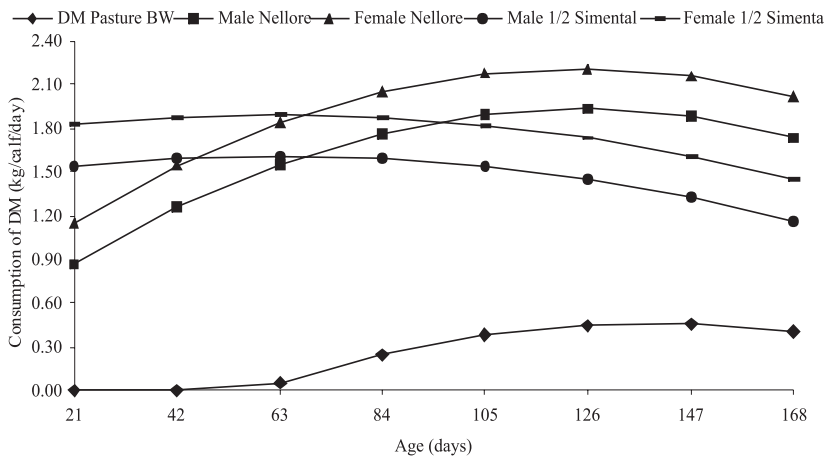

Figure 4 - Consumption of pasture, in DM, adjusted for body weight (BW) according to the age of calves and pasture, adjusted BW according to age, sex and genetic group.

Table 5 - Consumption of pasture in the dry matter, unadjusted and adjusted for body weight (BW) of Nellore cows, with their equations and regression

\begin{tabular}{|c|c|c|c|c|c|}
\hline Consumption (kg/cow/day) & Genetic group of calf & Mean & Standard error & $\mathrm{P}^{\mathrm{a}}$ & Regression $^{\mathrm{b}}$ \\
\hline \multirow[t]{2}{*}{ Unadjusted for BW } & Nellore & 9.32 & 0.460 & 0.3168 & c \\
\hline & $1 / 2$ Simental & 8.49 & 0.555 & & d \\
\hline \multirow[t]{2}{*}{ Adjusted for BW } & Nellore & 9.27 & 0.455 & 0.3172 & e \\
\hline & $1 / 2$ Simental & 8.64 & 0.556 & & f \\
\hline
\end{tabular}

a Probability of type I error in the difference between means.

${ }^{b}$ Days postpartum (D).

${ }^{c} \mathrm{Y}=5.26+0.08204 \mathrm{D}-0.000356 \mathrm{D}^{2}{ }^{\mathrm{d}} \mathrm{Y}=8.16-0.002615 \mathrm{D}+0.000023 \mathrm{D}^{2} .{ }^{\mathrm{e}} \mathrm{Y}=5.48+0.07493 \mathrm{D}-0.0003216 \mathrm{D}{ }^{\mathrm{f}} \mathrm{Y}=8.35-0.00454 \mathrm{D}+0.000034 \mathrm{D}^{2}$. 
In this study, the average calf consumption of pasture was approximately $1.1 \%$ of their body weight (BW), or $35 \mathrm{~g} / \mathrm{kg}^{0.75}$, whereas the consumption of pasture + milk was around $1.9 \% \mathrm{BW}$ or $56 \mathrm{~g} / \mathrm{kg}^{0.75}$. These results probably reflect an underestimation of consumption of the calves, as was expected, given the total consumption of over $2 \%$ of BW or g/kg ${ }^{0.75}$ (NRC, 1987; Grings et al., 1996).

The average dry matter intake by cows, adjusted or unadjusted for body weight was not influenced by genetic group of the calf (Table 5). However, a significant interaction was detected $(\mathrm{P}=0.0315)$ between genetic group and days after birth (Figures 5 and 6).

As it can be seen, the consumption of pasture by cows remained within the estimates by NRC (1987), averaging around 2.1\% BW or $96 \mathrm{~g} / \mathrm{kg}^{0.75}$. Salman et al. (2000), in research with Gir cows producing on average $5.1 \mathrm{~L} /$ day,

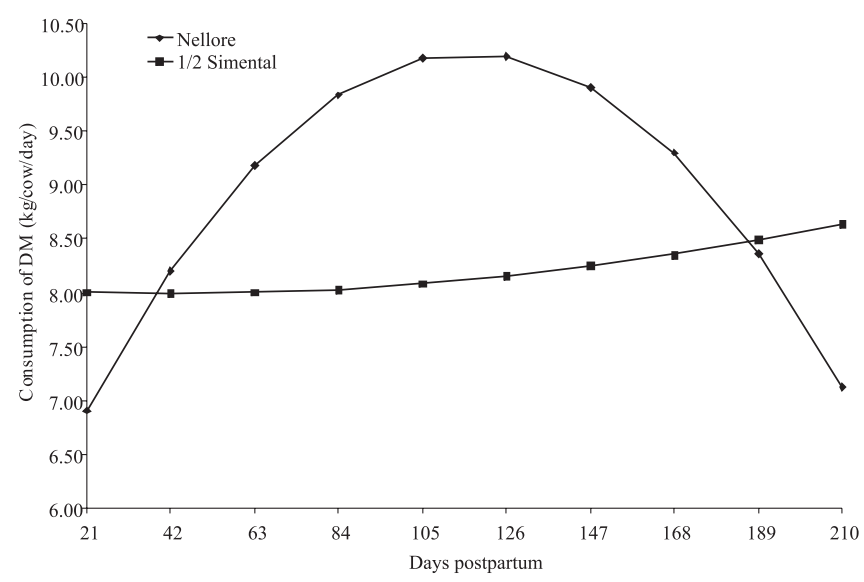

Figure 5 - The consumption of pasture dry matter, unadjusted for body weight of Nellore cows and separated by genetic group of the calf, as a function of days postpartum.

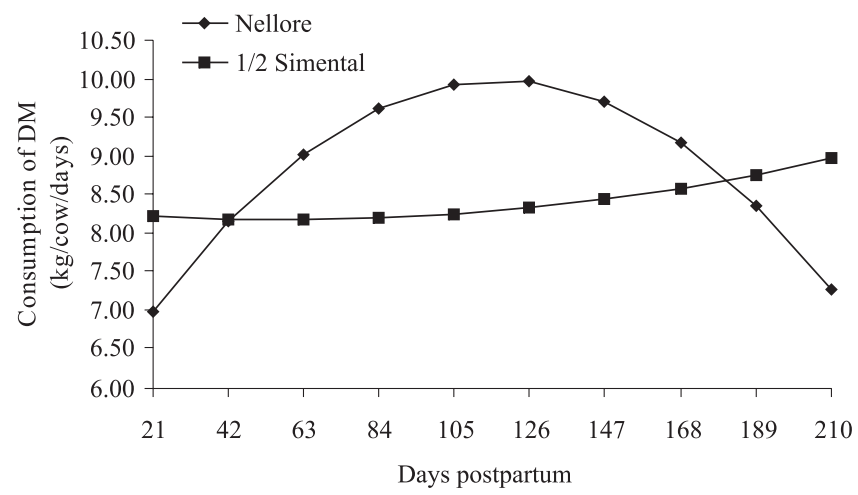

Figure 6 - The consumption of pasture dry matter (DM), adjusted to the body weight of Nellore cows and separated by genetic group of the calf, as function of the number of days postpartum. reported consumption of $9.5 \mathrm{~kg} /$ day $(2.3 \% \mathrm{BW})$ in a Tanzania pasture. Yet, Streets (1998), in experiments with Nellore cows in capim-jaraguá pasture (Hyparrhenia rufa) showed consumption of $8.93 \mathrm{~kg} \mathrm{DM}(2.1 \% \mathrm{BW}$ or 96 g MS/kg ${ }^{0.75}$ ).

However, in the present study, it was expected that the higher consumption of milk by crossbred calves would induce greater consumption of pasture by cows, although DM intake of cows to crossbred calves was approximately $8.5 \mathrm{~kg} /$ day, with slight increase during the postpartum period (Figures 5 and 6). In contrast, mothers of purebred Nellore calves started from a lower intake, around $7 \mathrm{~kg} /$ day and increased until reaching a maximum around 126 days postpartum, and then gradually reducing afterwards. Grings et al. (1996) also found no effect of breed of the calf on the consumption of cows, but the effect of body size and milk production of cows. According to NRC (1996), voluntary intake of beef cows is strongly related to the production of cow's milk in the postpartum period, and as milk production decreases, there should also be a corresponding decrease in forage intake, which was observed in this study.

\section{Conclusions}

Crossbred $1 / 2$ Simmental $\times 1 / 2$ Nellore calves ingest more milk and have higher growth rate compared with purebred Nellore calves. However, no significant differences in pasture consumption were found between the genetic groups. In Nellore cows, body weight and pasture consumption are not influenced by calf heterosis.

\section{References}

ALENCAR, M.M.; RUZZA, F.J.; PORTO, E.J.S. Desempenho produtivo de fêmeas das raças Canchim e Nellore. III. Produção de leite. Revista da Sociedade Brasileira Zootecnia, v.17, n.4, p.317-328, 1988.

ALENCAR, M.M.; TULLIO, R.R.; CRUZ, G.M. et al. Produção de leite da vaca e desenvolvimento do bezerro em gado de corte. Revista da Sociedade Brasileira Zootecnia, v.25, n.1, p.92-101, 1996. ANSOTEGUI, R.P.; HAVSTAD, K.M.; WALLACE, J.D. et al. Effects of milk intake on forage intake and performance of suckling range calves. Journal of Animal Science, v.69, n.3, p.899-904, 1991.

ASSOCIATION OF OFFICIAL ANALYTICAL CHEMISTS - AOAC. Official methods of analysis. 16.ed. Washington, D.C.: 1995. 1018p.

BAKER, R.D.; LE DU, Y.I.P.; BAKER, J.M. Milk fed calves. I. The effect of milk intake upon the herbage intake on calf performance of grazing calves. Journal of Agricultural Science, v.87, n.1, p.187-196, 1976.

BARBOSA, P.F.; ALENCAR, M.M. Sistema de cruzamento em bovinos de corte: estado da arte e necessidades de pesquisa. In: REUNIÃO ANUAL DA SOCIEDADE BRASILEIRA DE 
ZOOTECNIA, 32., 1995, Brasília, Anais... Brasília: SBZ, 1995. p.681-683.

BOGGS, D.L.; SMITH, E.F.; SCHALLES, R.R. et al. Effects of milk and forage intake on calf performance. Journal of Animal Science, v.51, n.3, p.550-553, 1980.

BREMER NETO, H.; GRANER, C.A.F.; PEZZATO, L.E. et al. Determinação de rotina do crômio em fezes, como marcador biológico, pelo método espectrofotométrico ajustado da 1,5difenilcarbazida. Ciência Rural, v.35, n.3, p.691-697, 2005.

BERCHIELLI, T.T.; SILVEIRA, R.N.; FURLAN, C.L. Efeito do método de colheita do capim coastcross (Cynodon dactylon (L.) Pers) sobre a digestibilidade "in vitro" da matéria seca. ARS Veterinária, v.18, n.1, p.83-87, 2002.

CALEGARE, L.; ALENCAR, M.M.; PACKER, I.U. et al. Cow/calf preweaning efficiency of Nellore and Bos taurus x Bos indicus crosses. Journal of Animal Science, v.87, n.2, p.740-747, 2009.

CRUZ, G.M.; ALENCAR, M.M.; TUlLiO, R.R. Produção e composição do leite de vacas das raças Canchim e Nellore. Revista Brasileira de Zootecnia, v.26, n.5, p.887-893, 1997.

DAY, M.L.; IMAKAWA, K.; CLUTTER, A.C. et al. Suckling behavior of calves with dams varying in milk production. Journal of Animal Science, v.65, n.5, p.1207-1212, 1987.

ESPASANDIN, A.C.; PACKER, I.U.; ALENCAR, M.M. Produção de leite e comportamento de amamentação em cinco sistemas de produção de gado de corte. Revista Brasileira de Zootecnia, v.30, n.3, p.702-708, 2001.

EUCLIDES, V.P.B.; MACEDO, M.C.M.; OLIVEIRA, M.P. Avaliação de diferentes métodos de amostragem (para estimar o valor nutritivo de forragens) sob pastejo. Revista da Sociedade Brasileira Zootecnia, v.21, n.4, p.691-702, 1992.

FELTEN, H.G.; MOLETTA, J.L.; RESTLE, J. et al. Efeito genético e nutricional sobre a composição do leite de vacas de corte, do parto à desmama. In: REUNIÃO ANUAL DA SOCIEDADE BRASILEIRA DE ZOOTECNIA, 26., 1989, Porto Alegre, Anais... Porto Alegre: SBZ, 1989. p.355.

FISS, C.F.; WILTON, J.W. Contribution of breed, cow weight, and milk yield to the pre-weaning, feedlot and carcass traits of calves in three beef breeding systems. Journal of Animal Science, v.71, n.11, p.2874-2884, 1993.

GOERING, H.K.; VAN SOEST, P.J. Forage fiber analysis. USDA: Agricultural Handbook. Washington, D.C., 1970. 379p.

GRINGS, E.E.; SHORT, R.E.; MacNEIL, M.R. et al. Efficiency of production in cattle of two growth potentials on northern great plains rangelands during spring-summer grazing. Journal of Animal Science, v.74, n.10, p.2317-2326, 1996.

HODGSON, J.; MATTHEWS, P.N.P.; MATTHEW, C. et al. Pasture measurement. In: HODGSON, J.; WHITE, J. New Zeland: pasture and crop science. Auckland, New Zeland: Oxford, 2000. p.59-66.

LANGLANDS, J.P.; CORBETT, J.L.; McDONALD, I. et al. Estimation of the faeces ouput o of grazing animals from the concentrationof chromium sesquioxide in a sample of faeces. 1. Comparioson of estimates from samples taked a fixed times of day with faeces ouputs measured directly. British Journal Nutriotion, v.17, n.2, p.211-218, 1963

LE DU, Y.I.P.; BAKER, R.D. Milk fed calves. 5. The effect of a change in milk intake upon the herbage intake and performance of grazing calves. Journal Agricultural Science, v.92, n.2, p.443-447, 1979.

LITTELL, R.C.; MILLIKEN, G.A.; STROUP, W.W. et al. SAS ${ }^{\circledR}$ system for mixed models. Cary: SAS Institute Inc., 1996. 633p.

MOLLETA, J.L.; RESTLE, J.; FELTEN, H.G. Relação entre a produção de leite de vacas Charolês e Nellore sobre o desempenho dos seus terneiros. In: REUNIÃO ANUAL DA SOCIEDADE BRASILEIRA DE ZOOTECNIA, 26., 1989, Porto Alegre, Anais... Porto Alegre: SBZ, 1989. p.357.

NATIONAL RESEARCH COUNCIL - NRC. Predicting feed intake of food-producing animals. Washington, D.C., 1987. 85p.

NATIONAL RESEARCH COUNCIL - NRC. Nutrient requirements of beef cattle. Washington, D.C., 1996. 233p.

OWENS, F.N.; HANSON, C.F. External and internal markers for appraising site and extent of digestion in ruminants. Journal of Dairy Science, v.75, n.9, p.2605-2617, 1992.

PENNING, R.D.; JOHNSON, R.H. The use of internal maskers to estimate herbage digestibility and intake: II. Indigestible acid detergent fiber. Journal Agricultural Science, v.100, n.1, p.133-138. 1983.

RANDEL, R.D. Nutrition and postpartum rebreeding in cattle. Journal of Animal Science, v.68, n.3, p.853-862, 1990.

RESTLE, J.; MOLLETA, J.L.; FELTEN, H.G. et al. Efeito genético e da alimentação sobre a produção sobre a produção de leite de vacas de corte e desempenho de seus terneiros, do parto ao desmame. In: REUNIÃO ANUAL DA SOCIEDADE BRASILEIRA DE ZOOTECNIA, 26., 1989, Porto Alegre. Anais... Porto Alegre: Sociedade Brasileira de Zootecnia, 1989. p.356.

RIBEIRO, E.L.A.; RESTLE, J. Desempenho de terneiros Charolês e Aberdeen Angus puros e seus mestiços com Nellore. Pesquisa Agropecuária Brasileira, v.26, n.8, p.1145-1151, 1991.

RIBEIRO, E.L.A.; RESTLE, J.; PIRES, C.C. Produção e composição de leite em vacas Charolês e Aberdeen Angus amamentando terneiros puros e mestiços. Pesquisa Agropecuária Brasileira, v.26, n.8, p.1267-1273. 1991.

ROVIRA, J. Manejo nutritivo de los rodeos de cria em pastoreo. Montevideo: Editorial Hemisferio Sur, 1996. 288p.

ROVIRA, J. Reproduccion y manejo de los rodeos de cria. Montevideo: Editorial Hemisferio Sur, 1973. 293p.

RUAS, J.R.M. Eficiência reprodutiva e perfil metabólico de vacas zebu em relação a status reprodutivo, condição corporal, amamentação diferenciada e suplementação alimentar. 1998. 107f. Tese (Doutorado em Zootecnia) - Universidade Federal de Viçosa, Viçosa, MG.

RUTLEDGE, J.J.; ROBISON, O.W.; AHLSCHWEDE, W.T. et al. Milk yield its influence on 205 day weight of beef calves. Journal of Animal Science, v.33, n.3, p.563-567, 1971.

SALMAN, A.K.D.; BERCHIELLI, T.T.; SILVEIRA, R.N. et al. Degradabilidade in situ do capim Panicum maximum cv. Tanzânia incubado cortado ou na forma de extrusa. Revista Brasileira de Zootecnia, v.29, n.6, p.2142-2149, 2000 (supl.).

VAN SOET, P.J. Nutritional ecology of the ruminant. 2.ed Ithaca: Cornell University, 1994. 476p.

VARGAS JUNIOR, F.M.; WECHSLER, F.S.; ROSSI, P. et al. Ingestive behavior of Nellore cows and their straightbred or crossbred calves. Revista Brasileira Zootecnia, v.39, n.3, p.648-655, 2010. 